\title{
Delayed Ultrastructural Lung Maturation in the Fetal and Newborn Hypothyroid (Hyt/Hyt) Mouse
}

\author{
DAPHNE E. DEMELLO, SARAH HEYMAN, R. GOVINDARAJAN, \\ ILENE R. S. SOSENKO, AND UDAY P. DEVASKAR
}

\author{
Departments of Pathology and Pediatrics, St. Louis University School of Medicine, and the \\ Pediatric Research Institute, St. Louis, Missouri 63104 [D.E.deM., S.H., R.G., U.P.D./, and the \\ Department of Pediatrics, University of Miami, Miami, Florida 33101 [I.R.S.S.]
}

ABSTRACT

\begin{abstract}
Thyroid hormones influence fetal and neonatal lung growth and maturation. However, the effect of naturally occurring, genetically determined hypo- or hyperthyroidism on fetal or neonatal lung maturation has not been examined. In the hyt/hyt mouse, primary hypothyroidism, which is characterized by a high serum TSH concentration, is transmitted as an autosomal recessive trait. It occurs due to a mutational defect in the $\beta$-subunit of the TSH receptor. We studied the lung ultrastructure of the fetal [18-dgestation (term $=\sim 19.5 \mathrm{~d}$ )] and neonatal (<1-d-old) hyt/ hyt mouse. In addition, disaturated phosphatidylcholine and total phospholipid contents of newborn hyt/hyt mouse lungs were determined. Male and female hyt/hyt mice with a high serum TSH concentration were made euthyroid by adding 3,5,3'-triiodothyronine to drinking water and then mated. Balb-c mice served as euthyroid controls. Fetal and neonatal hyt/hyt mice had a higher serum TSH concentration than the Balb-c controls. Fetal hyt/hyt mouse lungs
\end{abstract}

showed a large amount of intracellular glycogen and fewer lamellar bodies in epithelial type II cells compared with Balb-c fetal mouse lungs. The neonatal hyt/hyt mouse also showed signs of lung immaturity such as persistent epithelial cell glycogen, few lamellar bodies, reduced disaturated phosphatidylcholine content, and absent tubular myelin. We conclude that fetal and neonatal lung maturation is delayed in the hyt/hyt mouse with primary hypothyroidism. (Pediatr Res 36: 380-386, 1994)

TH, thyroid hormone

\section{Abbreviations}

$\mathbf{T}_{\mathbf{3}}, 3,5,3^{\prime}$-triiodothyronine

EM, electron microscopy

LB, lamellar body

TM, tubular myelin

TPL, total phospholipid

DSPC, disaturated phosphatidylcholine
TH are potent regulators of fetal and neonatal lung growth and maturation, whereas hypothyroidism is associated with a maturational delay $(1,2)$. Naturally occurring, genetically determined hypothyroidism in the mouse is a useful model for studying the effect of TH deficiency (3-8). In the hyt/hyt mouse, primary hypothyroidism is transmitted as an autosomal recessive trait and is due to a mutational abnormality in the TSH receptor (7). Adult and adolescent homozygous hyt/hyt mice have small thyroid glands with a decreased number of follicles, very low serum TH concentration, and markedly elevated serum TSH activity (4-8). In this study, we have characterized the hypothyroid state and analyzed lung ultrastructure in the hyt/hyt mouse fetus and 1-d-old pup and quantitated newborn lung DSPC and TPL content.

Received November 29, 1993; accepted March 24, 1994.

Correspondence and reprint requests: Daphne E. deMello, M.D., Department of Pediatric Pathology, Cardinal Glennon Children's Hospital, 1465 S. Grand Blvd., St. Louis, MO 63104.

\section{METHODS}

Animal care and euthanasia. The study protocol for the use of Balb hyt/hyt and normal Balb/c $(+/+)$ mice was approved by the Animal Care Committee of St. Louis University. Care of these mice was in accord with the guidelines set by the National Institutes of Health. Our colony of genetically hypothyroid mice was established from two homozygous (hyt/hyt) males and two heterozygous (hyt/ + ) females (Jackson Laboratories, Bar Harbor, ME). Mice were housed individually and allowed to eat food and drink water ad libitum. To restore fertility, $\mathrm{T}_{3}$ was added to the drinking water $(0.2$ $\mu \mathrm{g} / \mathrm{mL}$ ) of male mice. Homozygous mice could be separated easily from the heterozygous litter mates by $\sim 4$ wk of age because of small size and weight, low activity, and decreased amount of fur (4-8). To restore normal growth and restore fertility, $T_{3}$ was then added to the drinking water of homozygous male and female mice. Within 5 to 6 mo of $T_{3}$ substitution, hyt/hyt mice grew normally and were able to reproduce. To verify 
hypothyroid status, $\mathrm{T}_{3}$ supplementation was stopped for a month. Blood from the orbital sinus was collected under light Metofane (methoxyflurane, Pitman-Moore Co., Mundelein, IL) anesthesia. Homozygous (hyt/hyt) males and females were identified by a high serum TSH concentration and were allowed to produce hyt/hyt pups. During the breeding period, these mice received $\mathrm{T}_{3}$ water. Females were separated from the males when mating had occurred (positive vaginal plug $=\mathrm{d} 1$ of pregnancy; term $=\sim 19.5 \mathrm{~d}) . \mathrm{T}_{3}$ water was stopped at $\mathrm{d}$ 12 of pregnancy $(8)$. For fetal studies, all pregnant mice were killed with pentobarbitone $(100 \mathrm{mg} / \mathrm{kg}$, intraperitoneally) on d 18 of gestation. Maternal weight and orbital sinus blood were obtained before the mice were killed. Fetuses were delivered and weighed, and seeping blood from the neck vessels was collected in capillary tubes. For the neonatal studies, pups $<16 \mathrm{~h}$ old were weighed and blood from the neck vessels was collected. Blood from all pups within the litter was pooled. All pups were killed by cervical dislocation. A similar protocol was followed for the Balb/c $(+/+)$ mice, which served as euthyroid controls (4-7). To eliminate interlobar variability, the upper lobe of the right lung from a representative pup in each litter (fetushyt $/$ hyt $n=5$, Balb/c $n=4$; newborn-hyt/hyt $n=3$, $\mathrm{Balb} / \mathrm{c} n=3$ ) was saved for EM.

RIA for serum TSH. Recently, a sensitive and specific RIA for rat serum TSH has become available (Amersham Corp., Arlington Heights, IL). It has been established that mouse TSH cross reacts with the rat TSH antibody (6-8). Therefore, we used this kit to determine mouse serum TSH concentration. The sensitivity of the assay is $0.00005 \mu \mathrm{g}$ per tube. Within- and between-assay coefficient of variation is less than $10 \%$.

Because of the small size of these pups, enough serum was not available to quantitate thyroxine or $T_{3}$ concentration.

Lung EM. A slice from the middle of the right upper lobe was diced into $1-\mathrm{mm}$ cubes and fixed in $2 \%$ glutaraldehyde in PBS for $2 \mathrm{~h}$. The samples were processed through graded acetone and embedded in Spurr (Polysciences, Inc., Warrington, PA). Two blocks were randomly chosen for $1-\mu \mathrm{m}$ sectioning and, of these, one was chosen for thin sectioning based on predominance of saccules and absence of preacinar airways. The blocks were thin sectioned, mounted on copper grids, and counterstained with Reynold's lead and uranyl acetate. For each animal, 10 randomly selected areas in the section were photographed using a JEM-100S electron microscope, JEOL Ltd., Tokyo, Japan. The photographs were printed to produce a final magnification of $9000 \times$, and a morphometric analysis was done with the use of an interactive computerized image analysis program (Optimas, Bioscan Inc., Edmonds, WA). Type II cells were defined as plump, cuboidal cells with microvilli present on the surface of an air space. The number of type II cells in a unit area, number of type II cells that contained $\mathrm{LB}$, and number of LB in a unit area were counted. From these data, the average number of LB per type II cell was calculated. In addition, the volume densities of intracellular glycogen and the nucleus were obtained using the electron micrographs, a 100-point grid, and the Chalkley point-counting system (9). The presence or absence of TM was noted. For each pup, the means of these data from all electron micrographs were calculated. The means for each group, hyt/hyt or Balb/c, fetus or newborn, were derived. Each average measurement in the hyt/hyt or control group was compared.

Lung phospholipid assay. The fetal lung DSPC and TPL content were not quantitated due to lack of adequate tissue within each litter. The lungs from all the newborn pups in a litter were pooled and DSPC and TPL content were determined as described previously $(10,11)$, according to the method of Bligh and Dyer (12), Mason et al. (13), and Morrison (14). DSPC and TPL concentrations were expressed as $\mathrm{mg} / \mathrm{g}$ of wet lung and $\mathrm{mg} / \mathrm{mg}$ of lung homogenate protein, respectively (10).

Statistics. All data are mean \pm SEM. Statistical significance for the adult serum TSH concentration among hyt/t, hyt/hyt, or Balb/c $(+/+)$ mice was derived by analysis of variance. All data among hypothyroid (hyt/ hyt) or euthyroid $(+/+)$ fetuses or the newborns were compared by $t$ test.

\section{RESULTS}

\section{Serum TSH Concentration and Maternal, Fetal, and Newborn Mouse Data}

Mouse TSH standards were not available; therefore, the serum TSH concentration, expressed as $\mu \mathrm{g} / \mathrm{L}$, was based on the rat TSH standards. The serum TSH concentration $(\mu \mathrm{g} / \mathrm{L})$ in the adult homozygous (hyt/hyt) mouse was significantly higher (female, $81.7 \pm 5.5, n=$ 25; male, $81.3 \pm 9.5, n=18$ ) than that in the heterozygous $(\mathrm{hyt} /+)($ female, $3.2 \pm 0.1, n=10$; male, $5.7 \pm 0.1$, $n=6$ ) or the Balb/c $(+/+)$ (female, $3.9 \pm 0.5, n=8$; male, $4.6 \pm 0.3, n=8$ ) mouse. The maternal and fetal weight at $18 \mathrm{~d}$ of gestation; newborn weight; number of pups in a litter (fetus + newborn); and maternal, fetal, and newborn serum TSH concentration are shown in Table 1. The maternal weight at $18 \mathrm{~d}$ of gestation in the hyt/hyt and Balb-c mice was similar, indicating that the hyt/hyt mice were not in a catabolic state. Although fetal weights in the hyt/hyt and Balb-c mice were comparable, hyt/hyt newborns weighed less than the corresponding controls. In the hyt/hyt group, the mortality within $24 \mathrm{~h}$ of birth was higher $(\sim 10 \%)$ than in the controls $(\sim 1 \%)$. The hyt/hyt fetal and neonatal serum TSH concentrations were significantly higher than the corresponding values in Balb-c controls (Table 1).

\section{Lung EM}

Fetus. The control Balb-c mouse fetus at $18 \mathrm{~d}$ gestation had well-developed alveolar spaces lined by type II 
Table 1. Maternal, fetal and neonatal data in hyt/hyt and Balb-c mice*

\begin{tabular}{|c|c|c|}
\hline & $\begin{array}{c}\text { Hypothyroid } \\
\text { (hyt/hyt) }\end{array}$ & $\begin{array}{c}\text { Euthyroid control } \\
(\mathrm{Balb} / \mathrm{C})\end{array}$ \\
\hline Maternal weight at $18 \mathrm{~d}$ of gestation $(\mathrm{g})$ & $\begin{array}{c}39.5 \pm 1.4 \\
(n=6)\end{array}$ & $\begin{array}{c}42.4 \pm 2.4 \\
(n=5)\end{array}$ \\
\hline Maternal serum TSH concentration at $18 \mathrm{~d}$ of gestation $(\mu \mathrm{g} / \mathrm{L})$ & $\begin{aligned} 12.9 & \pm 7.6 \\
(n & =6)\end{aligned}$ & $\begin{array}{l}4.9 \pm 2.1 \\
(n=5)\end{array}$ \\
\hline Fetal weight at $18 \mathrm{~d}$ of gestation $(\mathrm{g})$ & $\begin{array}{c}0.62 \pm 0.03 \\
(n=6)\end{array}$ & $\begin{array}{c}0.77 \pm 0.1 \\
(n=5)\end{array}$ \\
\hline Fetal serum TSH concentration at $18 \mathrm{~d}$ of gestation $(\mu \mathrm{g} / \mathrm{L})$ & $\begin{array}{c}24.3 \pm 5.6 \dagger \\
(n=6)\end{array}$ & $\begin{array}{l}9.60 \pm 0.70 \\
(n=4)\end{array}$ \\
\hline Newborn (<1 d) weight (g) & $\begin{array}{c}1.24 \pm 0.65 \dagger \\
(n=9)\end{array}$ & $\begin{array}{c}1.59 \pm 0.1 \\
(n=9)\end{array}$ \\
\hline Newborn (1 d) serum TSH concentration $(\mu \mathrm{g} / \mathrm{L})$ & $\begin{array}{c}35.9 \pm 6.4 \dagger \\
(n=11)\end{array}$ & $\begin{array}{l}7.9 \pm 1.1 \\
(n=9)\end{array}$ \\
\hline Newborn mortality within $1 \mathrm{~d}$ of life & $10 \% \dagger$ & $1 \%$ \\
\hline Number of pups/litter & $\begin{array}{r}7.7 \pm 0.6 \\
(n=17)\end{array}$ & $\begin{array}{l}6.5 \pm 0.7 \\
(n=14)\end{array}$ \\
\hline
\end{tabular}

* All data are mean \pm SEM. $n=$ number of litters.

$\dagger p<0.01$ vs control.

epithelial cells containing mature LB at the cell apex (Figs. 1 and 2). Secreted membranous vesicles were present within alveolar spaces. In the 18-d fetal hyt/hyt mouse lung, the air spaces were small and the epithelial cells plump, giving the lung a more glandular appearance (Fig. 1). Fetal hyt/hyt mouse lungs contained significantly fewer LB per unit area of lung and per type II cell (Table 2). These lungs demonstrated a trend toward an increased ratio of volume density of type II cell glycogen to nucleus compared with control Balb-c fetuses.

Newborn. The 1-d-old Balb-c mouse lung contained well-developed air spaces lined by type II cells containing abundant LB and no cytoplasmic glycogen (Fig. 3). Air spaces contained many secreted LB and TM. Interalveolar septa were attenuated and thin, and many air-blood barriers were present. The 1-d-old hyt/hyt mouse lung, however, had thick alveolar septa and smaller air spaces. There was a trend toward fewer intracellular LB, and cytoplasmic glycogen was significantly increased compared with that in the Balb-c controls (Table 2). Fewer secreted air space LB and air-blood barriers were present, and TM was absent.

\section{Newborn Lung DSPC and TPL Content}

Lung DSPC content was significantly reduced in hyt/ hyt pups compared with that in controls (Table 3 ). However, TPL content was not different in hyt/hyt and control pups.

\section{DISCUSSION}

In this study, we have established primary hypothyroidism in the 18-d-gestation fetus and 1-d-old hyt/hyt mouse. In addition, we have demonstrated impaired structural lung maturation and reduced DSPC content in hypothyroid pups. The hypothyroid newborns weighed less than the controls. We do not have an explanation for the reduced body weight of hyt/hyt newborn pups. It could be due to alterations in milk production; suckling; water; carbohydrate, lipid, or protein metabolism; or a combination of these factors.

Hypothyroidism in the hyt/hyt adult and $\sim 4$-wk-old mouse has been determined by the presence of a high serum TSH-like activity (4-8) and low serum thyroxine and $T_{3}$ concentrations (4-8). To characterize hypothyroidism in the fetus and newborn mouse, we bred homozygous hyt/hyt male and female mice made euthyroid by the addition of $T_{3}$ to the drinking water. Serum TSH concentrations were determined with a sensitive RIA in the fetal and newborn offspring produced by this mating. In both the hyt/hyt fetus and newborn mouse, the serum TSH concentrations were significantly higher than those in the age-matched Balb-c euthyroid controls, establishing primary hypothyroidism in the hyt/hyt model. Serum TH concentration could not be quantitated in the fetus or the newborn mouse because of limited availability of serum and lack of a sensitive assay for serum TH.

Previous investigators have induced fetal or neonatal hypothyroidism by surgical or pharmacologic thyroidectomy to study the effect of TH deficiency on lung growth and maturation (15-17). Surgical thyroidectomy is stressful, cumbersome, and feasible only in large animals; it also leads to inadvertent parathyroidectomy. The degree of pharmacologically induced fetal or neonatal hypothyroidism is unpredictable due to variable drug absorption and placental transfer $(8,16,17)$. Thyrostatic drugs also influence the metabolism of other organs (8). The hyt/hyt mouse model of primary hypothyroidism provides an opportunity to study the influence of TH deficiency on fetal and neonatal growth and development throughout gestation without manipulation of the intrauterine milieu.

Ultrastructural examination of the fetal hyt/hyt mouse lung at $18 \mathrm{~d}$ of gestation revealed a maturational delay manifested by smaller air spaces and plump epithelial cells containing more cytoplasmic glycogen and fewer LB compared with the control Balb-c mouse fetuses. In 


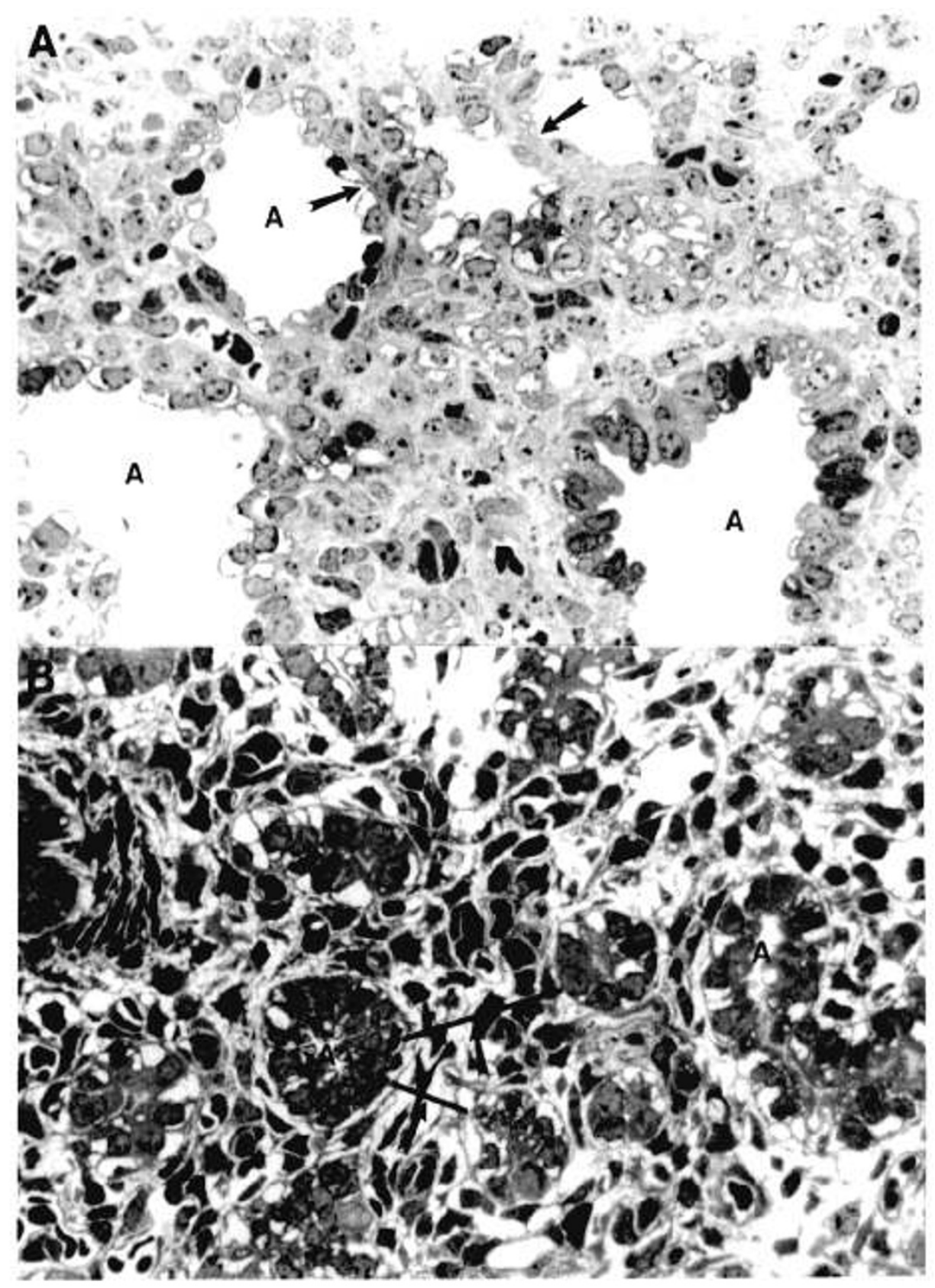

Figure 1. Light micrograph of fetal mouse lung at $18 \mathrm{~d}$ of gestation. $A$, Balb-c (control); $B$, hyt/hyt (hypothyroid). In $A$, note well-formed air spaces $(A)$ and thinned septa (short arrows). In $B$, the interstitium (short arrows) is thick and air spaces $(A)$ are poorly formed, giving the lung a glandular appearance. Magnification $\times 500$.

the 1-d-old hyt/hyt mouse, there was a persistence in cytoplasmic glycogen within lung epithelial cells, a reduced number of intracellular and secreted LB, and a reduced DSPC content, reflecting a continuing delay in biochemical lung maturation. TM, which was readily apparent in the Balb-c mouse, was not seen in the hyt/hyt newborn lungs. TM is the extracellular form of surfactant believed to be responsible for the formation of the surface monolayer-the most surface-active form of surfactant-at the air-liquid interface in the alveolus (18). The absence of TM in the hyt/hyt mouse lungs raises the possibility of an abnormality in the usual process of conversion of LB to TM. These aberrations may explain the increased mortality of hyt/hyt pups during the first 24 $h$ of life. The survival of the majority of the hypothyroid pups despite reduced DSPC content and absent TM is puzzling. It is possible that although the lung is immature it is still capable of sustaining life because of the lower metabolism and oxygen consumption in hypothyroidism (19). In addition to the surfactant proteins SP-A and SP-B, a specific ionic composition and $\mathrm{Ca}^{++}$concentration are necessary for the conversion of LB to TM (18). The developmental expression of lung SP-A and SP-B in primary hypothyroidism has not been studied.

In addition to the delay in biochemical maturation, the newborn hyt/hyt lungs revealed a significant delay in 


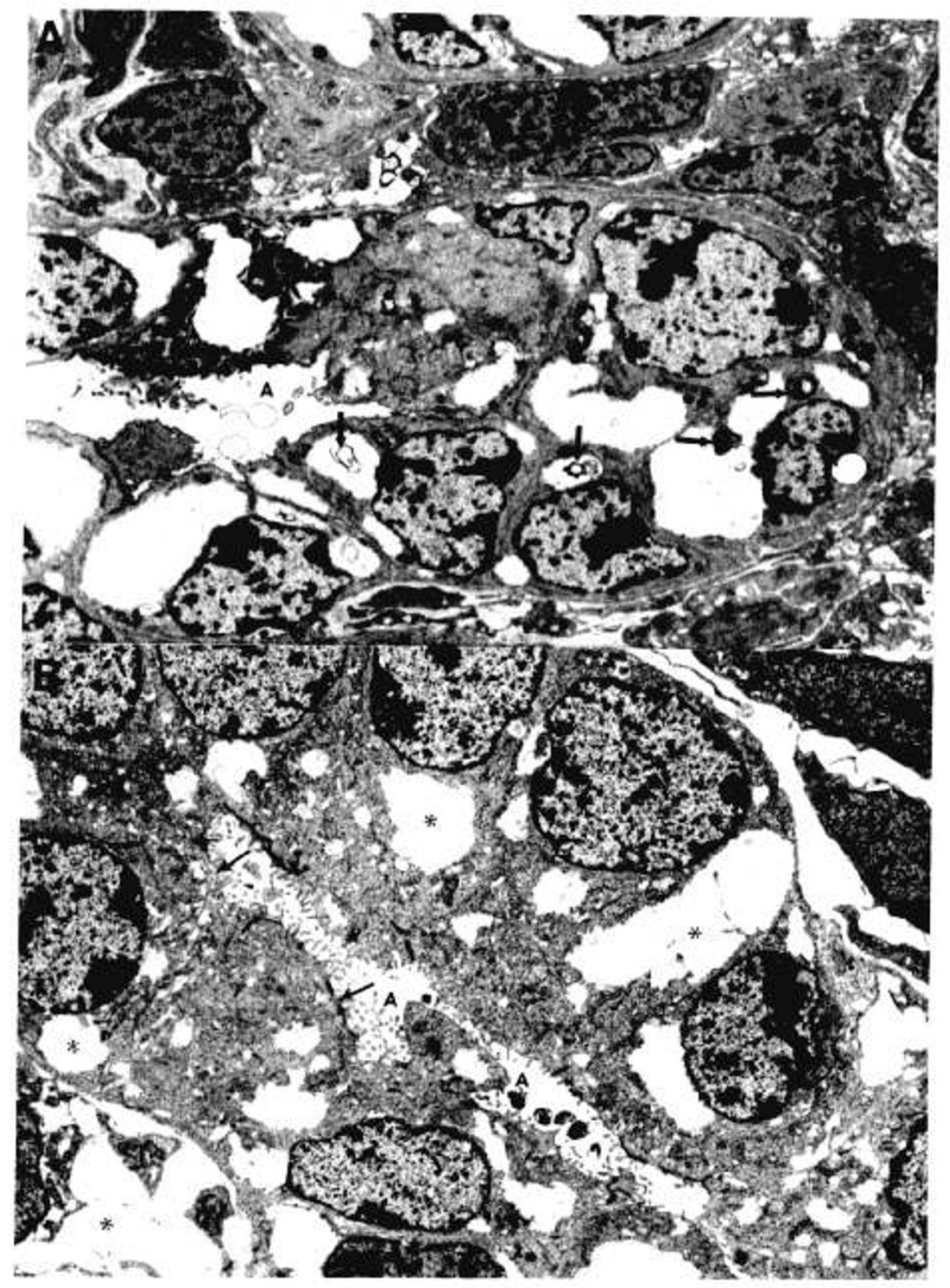

Figure 2. Electron micrograph of fetal mouse lung at $18 \mathrm{~d}$ of gestation. $A$, Balb-c (control); $B$, hyt/hyt (hypothyroid). In $A$, note well-developed LB (thick arrows) within type II cells and secreted membranous vesicles within alveolar spaces $(A)$. In $B$, large, empty cytoplasmic spaces $\left(^{*}\right)$ represent pools of glycogen removed during tissue processing. Note paucity of LB in type II cells (thin arrows) lining alveolar spaces $(A)$. Magnification $\times 9000$.

Table 2. Analysis of lung ultrastructural features*

\begin{tabular}{llcccc}
\hline & \multicolumn{2}{c}{ Fetus } & & \multicolumn{2}{c}{ Neonate } \\
\cline { 2 - 3 } & \multicolumn{1}{c}{$\begin{array}{c}\text { hyt/hyt } \\
(n=5)\end{array}$} & $\begin{array}{l}\text { Control } \\
(n=4)\end{array}$ & & $\begin{array}{l}\text { hyt/hyt } \\
(n=3)\end{array}$ & $\begin{array}{l}\text { Control } \\
(n=3)\end{array}$ \\
\hline Number of LB/unit area & $4.42 \pm 0.68 \dagger$ & $7.51 \pm 1.14$ & $6.94 \pm 2.02$ & $11.87 \pm 2.67$ \\
Number of LB/type II cell & $1.08 \pm 0.11 \dagger$ & $2.35 \pm 0.3$ & $2.93 \pm 0.59$ & $4.39 \pm 0.16$ \\
Number of type II cells with LB/unit area & $2.62 \pm 0.4$ & $3.08 \pm 0.23$ & & $2.33 \pm 0.57$ & $2.72 \pm 0.46$ \\
Glycogen/nucleus in type II cell & $0.80 \pm 0.09$ & $0.78 \pm 0.09$ & & $0.18 \pm 0.038 \dagger$ & $0.04 \pm 0.014$ \\
Number of type II cells/unit area & $4.23 \pm 0.65$ & $3.23 \pm 0.20$ & & $2.7 \pm 0.85$ & $2.75 \pm 0.44$ \\
\hline
\end{tabular}

* All data are mean \pm SEM. $n=$ number of litters studied.

$+p<0.02$ vs control. 


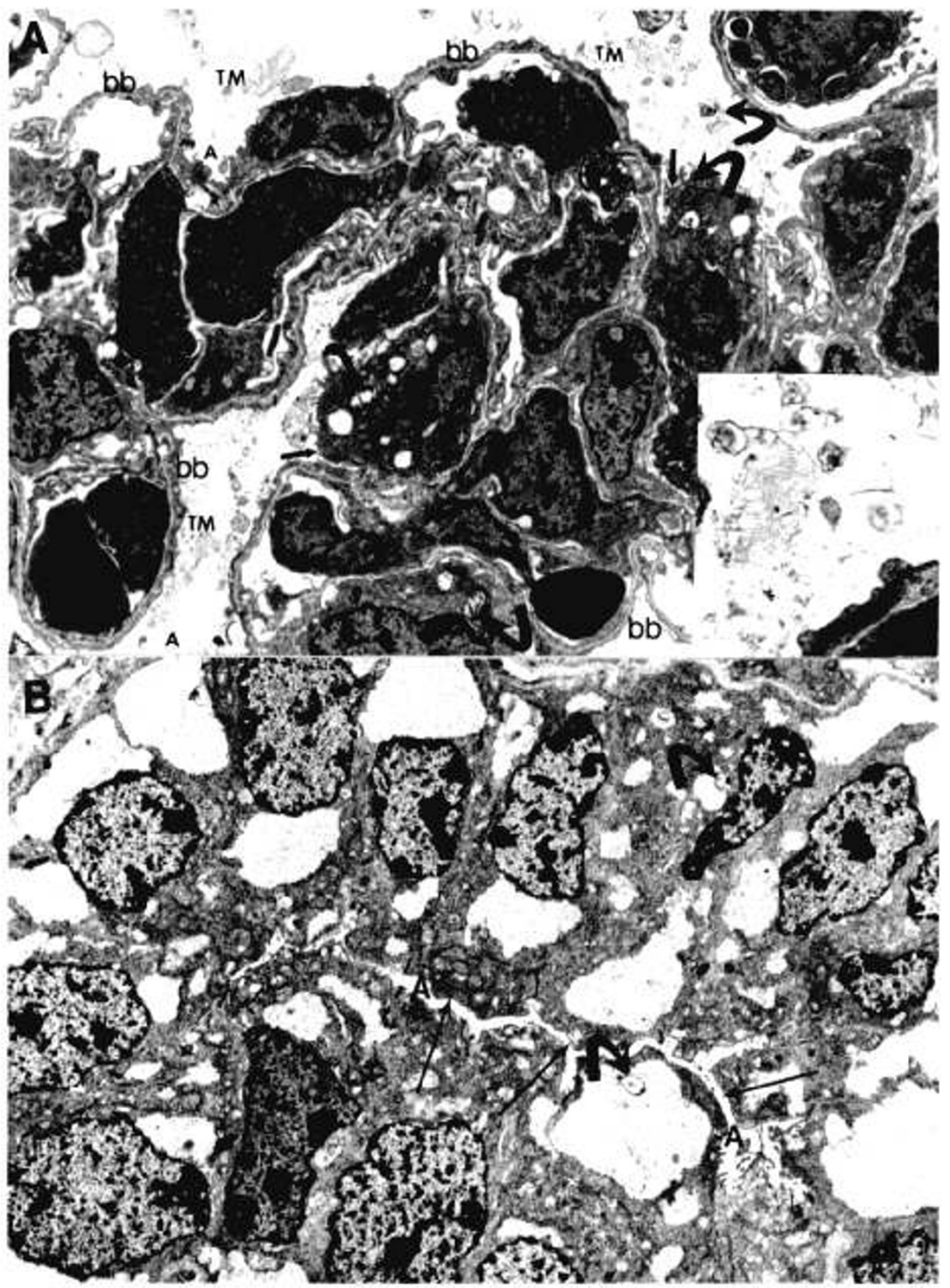

Figure 3. Electron micrograph of 1-d-old mouse lung. $A$, Balb-c (control); $B$, hyt/hyt (hypothyroid). In $A$, type II cells (short, thick arrows) are devoid of cytoplasmic glycogen but contain plenty of LB (curved arrows), which are also present in alveolar spaces along with abundant TM. Inset, Magnified view of TM. There are several air-blood barriers $(b b)$. In $B$, large amounts of cytoplasmic glycogen are present in type II cells $(t h i n$, long arrows) and LB (curved arrows) are scarce. TM is absent from the alveoli $(A)$ and air-blood barriers are not present.

structural maturation. The attenuation of interalveolar septa was not seen. Few air-blood barriers were present, indicating a delay in the normal migration of capillaries toward the alveolar lumen and in the fusion of the endo-

Table 3. DSPC and TPL content of lungs of newborn mice*

\begin{tabular}{lcc}
\hline & hyt/hyt $(n=5)$ & Control $(n=8)$ \\
\hline DSPC (mg/g of wet lung) & $3.67 \pm 0.27 \dagger$ & $4.66 \pm 0.24$ \\
DSPC (mg/mg of lung protein) & $0.0356 \pm 0.003 \dagger$ & $0.0455 \pm 0.0032$ \\
TPL (mg/g of wet lung) & $19.05 \pm 0.96$ & $21.35 \pm 0.71$ \\
TPL (mg/mg of lung protein) & $0.185 \pm 0.013$ & $0.211 \pm 0.0085$ \\
\hline
\end{tabular}

* All data are mean \pm SEM. $n=$ number of litters studied

$+p<0.05 v s$ control. thelial and epithelial cell basement membranes to form the air-blood barrier $(20,21)$. This aspect of lung morphogenesis requires the intricate interaction of epithelial cells with extracellular matrices and is under the control of a variety of mediators and cytokines (22). The presence of this structural abnormality in primary hypothyroidism suggests that $\mathrm{TH}$ play a role in normal lung cytodifferentiation. The molecular basis for this effect of TH on lung development remains unknown.

\section{REFERENCES}

1. Ballard P 1989 Hormonal regulation of pulmonary surfactant. Endocr Rev $10: 165-181$ 
2. Rooney SA 1985 The surfactant system and lung phospholipids. State of the art. Am Rev Respir Dis 131:439-460

3. Beamer WG, Eicher EM, Maltais LJ, Southard JL 1981 Inherited primary hypothyroidism in mice. Science 212:61-62

4. Stein SA, Shanklin DR, Krulich L, Roth MG, Chubb CM, Adams PM 1989 Evaluation and characterization of the hyt/hyt hypothyroid mouse. II. Abnormality of TSH and the thyroid gland. Neuroendocrinology 49:509-519

5. Adams PM, Stein SA, Palnitkar M, Anthony A, Gerrity L, Shanklin DR 1989 Evaluation and characterization of the hyt/hyt hypothyroid mouse. Neuroendocrinology 49:138-143

6. Beamer WG, Cresswell LA 1982 Defective thyroid ontogenesis in fetal hypothyroid (hyt/hyt) mice. Anat Rec 202:387-393

7. Stein SA, Zakarija M, McKenzie JM, Shanklin DR, Adams PM 1991 The site of molecular defect in the thyroid gland of the hyt/hyt mouse: abnormality in the TSH receptor-G protein adenylyl cyclase complex. Thyroid 1:257-265

8. Alm J, Scott S, Fisher DA 1986 Epidermal growth factor receptor ontogeny in mice with congenital hypothyroidism. J Dev Physiol 8:377-385

9. Chalkley HW 1941 Method for the quantitative morphologic analysis of tissues. J Natl Cancer Inst 4:47-49

10. Rodriguez MP, Sosenko IR, Anitgua MC, Frank L 1991 Prenatal hormone treatment with thyrotropin releasing hormone and with thyrotropin releasing hormone plus dexamethasone delays antioxidant enzyme maturation but does not inhibit a protective antioxidant enzyme response to hyperoxia in newborn rat lung. Pediatr Res 30:522-527

11. Sosenko IRS, Lewis PL, Frank L 1986 Metapyrone delays surfactant and antioxidant enzyme maturation in developing rat lung. Pediatr Res 20:672-675

12. Bligh EF, Dyer WJ 1959 A rapid method of total lipid extraction and purification. Can J Biochem Physiol 37:911-917
13. Mason RJ, Nellenbogen J, Clements JA 1976 lsolation of disaturated phosphatidylcholine with osmium tetroxide. J Lipid Res 17:281-284

14. Morrison WR 1964 A fast simple and reliable method for the microdetermination of phosphorous in biological materials. Anal Biochem 11:218-224

15. Erenberg A, Rhodes ML, Weinstein MW, Kennedy RL 1979 The effect of fetal thyroidectomy on ovine fetal lung maturation. Pediatr Res 13:230235

16. Devaskar SU, Ganguli S, Devaskar UP, Sperling MA 1982 Glucocorticoids and hypothyroidism modulate development of fetal lung insulin receptors. Am J Physiol 242:E384-E391

17. Massaro D, Teich N, Massaro GD 1986 Postnatal development of pulmonary alveoli: modulation in rats by thyroid hormones. Am J Physiol 250:R51-R55

18. Bourbon JR 1992 Secretion, alveolar processing, and turnover of pulmonary surfactant. In: Bourbon JR (ed) Pulmonary Surfactant: Biochemical, Functional. Regulatory and Clinical Concepts. CRC Press, Boca Raton, FL, pp $143-183$

19. Moshang Jr T, Bongiovanni AM 1987 Endocrine disorders in the newborn. In: Avery GB (ed) Neonatology, Pathophysiology and Management of the Newborn. JB Lippincott, Philadelphia, pp 129)-1292

20. Dimaio M, Gil J, Ciurea D, Katten M 1989 Structural maturation of the human fetal lung: a morphometric study of the development of the air blood barriers. Pediatr Res 26:88-93

21. Campiche MA, Gautier A, Hernandez EI, Reymond A 1963 An electron microscopic study of the fetal development of human lung. Pediatrics 32:976994

22. Crouch EC, Martin GR, Brody JS 1991 Basement membranes. In: Crystal RG, West JB (eds) The Lung. Raven Press, New York, pp 421-437 